\title{
EFFECTS OF ENZYME TREATMENT ON THE MICROFILTRATION OF ELDERBERRY
}

\author{
${ }^{1,3}$ D. Furulyás, ${ }^{2}$ F. Savanya, ${ }^{2}$ Sz. Bánvölgyi, ${ }^{3}$ N. Papp, ${ }^{3}$ É. Stefanivots-Bánya, ${ }^{1}$ M. Stéger-Máté \\ ${ }^{1}$ Department of Food Preservation, Faculty of Food Science, Szent István University, Villányi Street 29-43., H-1118, Budapest, \\ Hungary, \\ e-mail: furulyas.diana@phd.uni-szie.hu \\ ${ }^{2}$ Department of Food Engineering, Faculty of Food Science, SzIU, Ménesi Street 44., H-1118, Budapest, Hungary, \\ e-mail: Banvolgyi.Szilvia@etk.szie.hu \\ ${ }^{3}$ Department of Applied Chemistry, Faculty of Food Science, SzIU, Villányi Street 29-43., H-1118, Budapest, Hungary, \\ e-mail: Banyai.Eva@etk.szie.hu
}

\begin{abstract}
The aim of this study was to evaluate the effect of microfiltration (MF) on the antioxidant capacity of elderberry juice using ceramic membrane. Previous to MF measurements preliminary examination was achieved with different enzymes. Four different samples were prepared: one without any enzyme and three with different pectolytic enzymes. The resistances were determined using the resistance-in-series model and difference between four enzyme-treated samples are evaluated. The effect of this technology on the antioxidant component of the clarified elderberry juice has been evaluated in permeate and retentate samples. For ferric reducing antioxidant power was measured with FRAP and total phenolic content (TPC) was determined with Folin Ciocalteau reagent. The total anthocyanin content (TAC) was estimated using spectrophotometric method.

Higher juice yield was obtained using enzyme compared with enzyme-free elderberry pulp. The analytical results show that the MF membrane retained the valuable components in different rate. Significant losses are believed to have occurred after the MF clarification process due to fouling layer resistance, what can be decreased with pectolytic enzymes treatment.
\end{abstract}

Keywords: elderberry, microfiltration, enzyme treatment, antioxidant, polyphenol, anthocyanin

\section{INTRODUCTION}

Elderberry plant (Sambucus nigra L.) is a good source of many valuable components including amino acids, unsaturated fatty acids, vitamins and mineral elements. It contains high biological activity components: polyphenols, anthocyanins, flavonols, phenolic acids and proanthocyanidins [1]. The elderberry has been used in the treatment of many diseases and ailments in the folk medicines [2]. Reference [3] has shown that the antioxidant activity is exhibited by fruits, flowers and leaves of elderberry.

The antioxidant power of elderberry products is influenced by the steps of preparing method (enzymatic treatment, pressing, clarification etc.). Most of the studies concern changes these compounds in case of fruit juice $[4 ; 5 ; 6 ; 7]$.

In this study changes in antioxidant power (FRAP), polyphenol (TPC) and anthocyanin (TAC) content were investigated during juice microfiltration technology at the laboratory circumstances in case of four different enzyme-treated elderberry juice.

\section{MATERIALS AND METHODS}

\subsection{Materials}

The investigated elderberry was harvested in 2015 from grower Nagyvenyim, Hungary. Using for preliminary treatment of juice pectolytic enzymes, ErbiGel and Klar Sol Super were obtained from Kerttrade Ltd. All of the reagents for antioxidant measurements were analytical grade purchased from Sigma Aldrich Hungary Ltd. 


\subsection{Juice preparation and enzyme treatment}

Juice preparation was performed according to the industrial practice in the pilot plant of the Szent István University, Hungary (Department of Food Preservation).

After the wash and crush steps the berries were treated with three different pectolytic enzymes (Fructozyn BE, Pectinex XXL, Pectinex BE XXL) and one sample was prepared without any enzyme. The enzymes were added to the crushed fruit and left to stand for 1 hour, the amount of enzyme depend on the applied enzyme (Tab. 1) and according to the industrial practice. After the first treatment the pulps were pressed by manual press followed by second enzyme treatment with half amount of enzymes for 30 minutes.

Table 1. Parameters of enzyme treatment

\begin{tabular}{cccccc}
\hline \multirow{2}{*}{ Sample } & Enzyme & \multicolumn{2}{c}{ First enzyme treatment } & \multicolumn{2}{c}{ Second enzyme treatment } \\
\cline { 3 - 6 } & - & Time $(\mathrm{h})$ & $\begin{array}{c}\text { Amount } \\
\left(\mathrm{mg} \mathrm{kg}^{-1}\right)\end{array}$ & Time (h) & $\begin{array}{c}\text { Amount } \\
\left(\mathrm{mg} \mathrm{L}^{-1}\right)\end{array}$ \\
\hline 1 & - & - & - & - \\
2 & Fructozyn BE & 1 & 0.06 & 0.5 & 0.03 \\
3 & Pectinex XXL & 1 & 0.2 & 0.5 & 0.1 \\
4 & Pectinex BE XXL & 1 & 0.2 & 0.5 & 0.1 \\
\hline
\end{tabular}

Before filtration measurements the pulps were clarified with Klar Sol Super $\left(0.35 \mathrm{mg} \mathrm{L}^{-1}\right)$ left to stand for 20 minutes and ErbiGel $\left(0.1 \mathrm{mg} \mathrm{L}^{-1}\right)$ for 10 minutes.

\subsection{Microfiltration}

Microfiltration was carried out in the laboratories of the Szent István University, Hungary (Department of Food Engineering). For filtration of enzyme treated juice ceramic tube membrane was used with an average pore size of $0.8 \mu \mathrm{m}$ and a permeable area of $0.005 \mathrm{~m}^{2}$. Inside the tube membrane a static mixer was used to enhance the permeate flux. The applied transmembrane pressure was 3.5 bar and the temperature was $30^{\circ} \mathrm{C}$. Cross-flow filtration was applied to remove the suspended solids from the fresh elderberry juice. The scheme of microfiltration apparatus can be shown on the Fig. 1. where juice was recirculated by a pump to the membrane surface. The transmembrane pressure (TMP), the pressure the difference between the two sides of the membrane is the driving force of filtration. Before clarification the pure water and juice flux were determined. The MF apparatus was used at constant $150 \mathrm{~L}^{*} \mathrm{~h}^{-1}$ recycle flow rate.

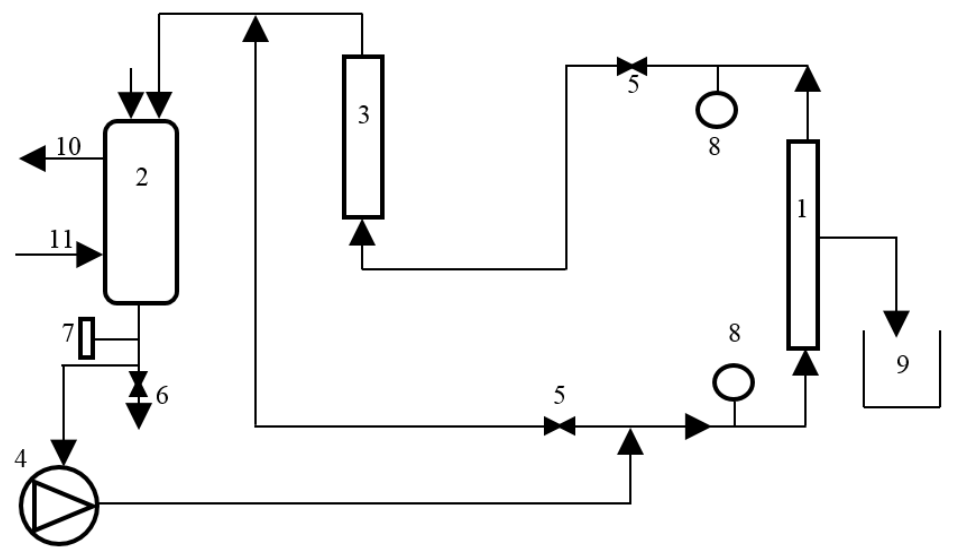

1 - membrane

2 - tank

3 - rotameter

4 - pump

5 - valve

6 - retentate

7 - thermometer

8 - manometer

9 - permeate

10 - cooling water input

11 - cooling water output

Figure 1. Scheme of MF apparatus 


\subsection{Resistances of filtrations}

The membrane-, the fouling resistance and resistance of the polarization cake layer were determined based on the experimental data [8] with the resistance-in-series model (1).

$$
J=\frac{\mathrm{TMP}}{\eta * \mathrm{R}_{T}}
$$

where $J$ is the permeate flux, TMP is the transmembrane pressure, $\eta$ is the viscosity of the permeate; $R_{T}$ is the total resistance of microfiltration (2).

$$
R_{T}=R_{M}+R_{F}+R_{C}
$$

where $R_{M}$ is the membrane resistance; $R_{F}$ is the fouling resistance (caused by solute adsorption into the membrane pores and walls), $R_{C}$ is the resistance of cake layer, in all cases the viscosity of solvent was taken into consideration. Before $\left(\mathrm{J}_{\mathrm{W}}\right)$ and after $\left(\mathrm{J}_{\mathrm{FW}}\right)$ filtrations permeate flux was measured with pure water. Each resistance value can be obtained through Equations (3-5).

$$
\begin{gathered}
\mathrm{R}_{\mathrm{M}}=\frac{\mathrm{TMP}}{\mathrm{J}_{\mathrm{W} * \eta_{\text {water }}}} \\
\mathrm{R}_{\mathrm{F}}=\frac{\mathrm{TMP}}{\mathrm{J}_{\mathrm{FW}} * \eta_{\text {water }}}-\mathrm{R}_{\mathrm{M}} \\
\mathrm{R}_{\mathrm{C}}=\frac{\mathrm{TMP}}{\mathrm{J} * \eta_{\text {juice }}}-\left(\mathrm{R}_{\mathrm{M}}+\mathrm{R}_{\mathrm{F}}\right)
\end{gathered}
$$

\subsection{Determination of antioxidant status}

Juice preparation was performed in the pilot plant of the Szent István University, Hungary (Department of Food Preservation).

These measurements were carried out from extracted juice. The extracting solvent included $60 \%$ distilled water, $29.9 \%$ methanol and $1 \%$ hydrochloric acid. Stock solutions were prepared by weighing $2 \mathrm{~g}$ of each into $50-\mathrm{mL}$ actinic volumetric flasks and bringing each to volume with extracting solvent.

Antioxidant power was determined by the ferric reducing antioxidant power assay (FRAP) [9]. The results are expressed in ascorbic acid equivalent (mmol AA E / L). Furthermore, the total polyphenol content (TPC) of the samples was also determined based on the method of Singleton and Rossi [10] at $765 \mathrm{~nm}$. Results are expressed in gallic acid equivalent (mmol GA E / L). The anthocyanin content was also estimated using a spectrophotometric method described for Fuleki \& Francis [11]. The absorbance (A) of samples was measured at $530 \mathrm{~nm}$, data was showed at milligram per litre (mg/L). A Hitachi U-2900 UVVIS spectrophotometer (Hitachi High-Technologies Europe GmbH, Krefeld, Germany) was used for photometric measurements. 


\subsection{Statistical analysis}

The statistical analysis has been made by Microsoft Excel 2013. The Student t-test was used to determined differences between resistances of four enzyme-treated samples during microfiltration and also testing for decide whether enzyme caused significant changes in antioxidant content. The $\mathrm{P}$ value $<0.05$ was considered to be significant.

\section{RESULTS AND DISCUSSION}

In this study four different enzyme treatments (Enzyme-free, Fructozyn BE, Pectinex XXL, Pectinex BE XXL) of elderberry were carried out. The antioxidant status was measured. The raw juice and microfiltrated juice (retentate, permeate) were compared.

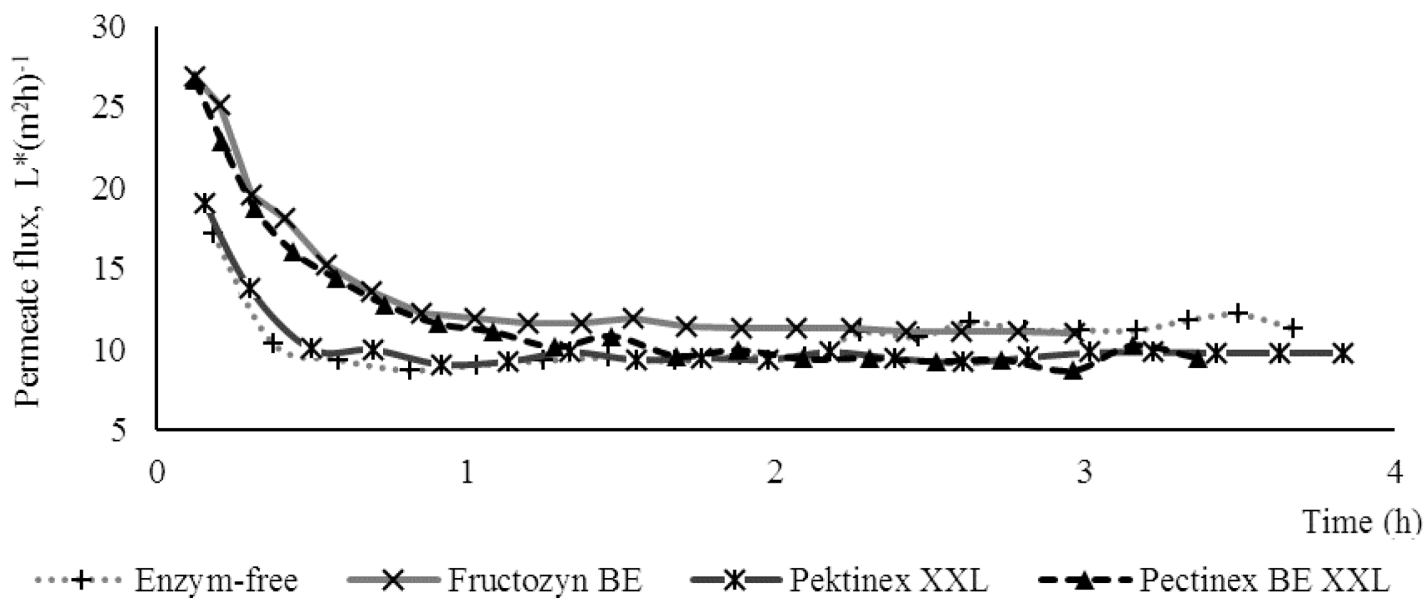

Figure 2. Effect of enzyme treatment on permeate flux during microfiltration.

The data shows the enzymes influenced the microfiltration as well as the permeate flux and the filtration time (Fig. 2). Enzyme treatment enhanced the permeate fluxes of juices and the filtration time was shorter than in case of Fructozyn BE and Pectinex XXL. The best result was using Fructozyn BE enzyme.

Table 2. Resistances of filtration

\begin{tabular}{ccccc} 
Resistance & Enzyme free & Fructozyn BE & Pectinex XXL & Pectinex BE XXL \\
\hline $\mathrm{R}_{\mathrm{M}}\left(10^{12} \mathrm{x} \mathrm{m}^{-1}\right)$ & $2.85 \pm 0.19_{\mathrm{a}}$ & $2.85 \pm 0.19_{\mathrm{a}}$ & $2.85 \pm 0.19_{\mathrm{a}}$ & $2.85 \pm 0.19_{\mathrm{a}}$ \\
$\mathrm{R}_{\mathrm{F}}\left(10^{12} \mathrm{x} \mathrm{m}^{-1}\right)$ & $30.59 \pm 1.13_{\mathrm{b}}$ & $20.48 \pm 1.22_{\mathrm{c}}$ & $15.63 \pm 1.42_{\mathrm{d}}$ & $26.14 \pm 1.82_{\mathrm{e}}$ \\
$\mathrm{R}_{\mathrm{C}}\left(10^{12} \mathrm{x} \mathrm{m}^{-1}\right)$ & $63.72 \pm 3.12_{\mathrm{f}}$ & $46.62 \pm 2.38_{\mathrm{g}}$ & $71.97 \pm 2.73_{\mathrm{h}}$ & $51.24 \pm 3.26_{\mathrm{i}}$ \\
$\mathrm{R}_{\mathrm{T}}\left(10^{12} \mathrm{x} \mathrm{m}^{-1}\right)$ & $97.16_{\mathrm{j}}$ & $69.95_{\mathrm{k}}$ & $90.45_{1}$ & $80.23_{\mathrm{m}}$
\end{tabular}

Mean \pm Standard Derivation

a. b. c. etc. Same letter indicates that the enzyme treatment didn't caused significant changes in resistances of microfiltration at $95 \%$ confidence.

Permeate flux of pure water was measured before every filtration of juice. The membrane resistance $\left(\mathrm{R}_{\mathrm{M}}\right)$ was calculated from this data (Eq. 3). 
Fouling resistance $\left(R_{F}\right)$ was determined from $R_{M}$ and permeate flux of pure water after filtration (Eq. 4). Results shows significant differences between the $R_{F}$ values and fouling resistance of Pectinex XXL juice is approximately half of the $\mathrm{R}_{\mathrm{F}}$ of enzym-free pulp.

Using Equation 5. the resistance of cake layer $\left(R_{C}\right)$ was calculated from $R_{F}$ and $R_{M}$. The $R_{C}$ values had a range from $51.24 * 10^{12}$ to $71.97 * 10^{12} \mathrm{~m}^{-1}$ and the significantly highest cake layer resistance was obtained in case of Pectinex XXL pulp. The lowest total resistance of microfiltration was determinated in case of Fructozyn BE enzym treated juice, the highest value was obtained at enzym free sample.

The effect of enzyme treatment and microfiltration technology on the antioxidant components of the clarified elderberry juice has been evaluated in raw, permeate and retentate samples. The antioxidant power, polyphenol and anhocyanin content were measured by spectrophotometric methods. Fig. 3. shows the results of anthocyanin measurement.
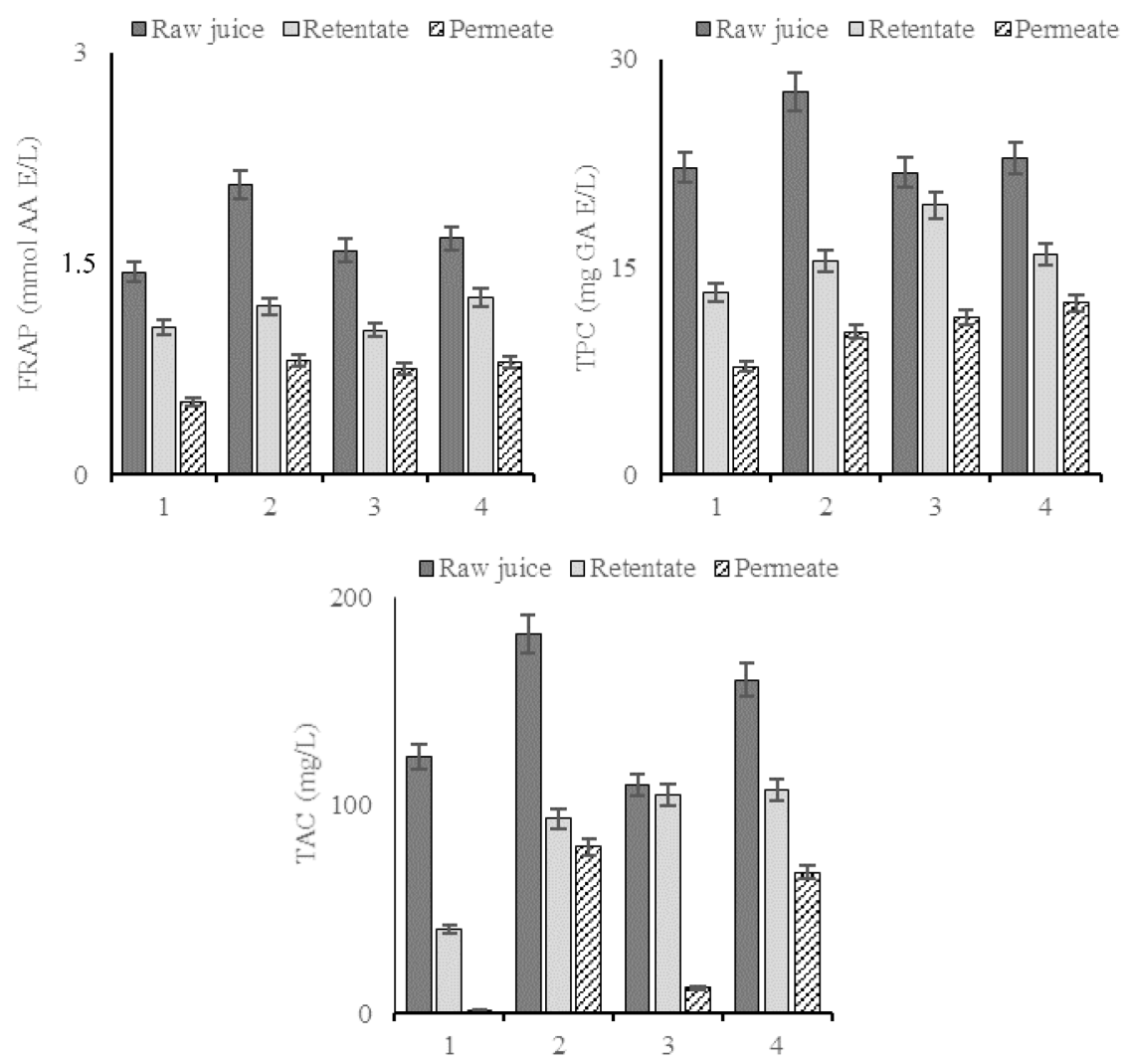

Figure 3. Avarage results of Antioxidant measurements

FRAP: Ferric reducing Ability Power; TPC: Total polyphenol content; TAC: Total anthocyanin content (data shown in mmol AAE/L for FRAP; $m g$ GAE/L for TPC; and $m g / L$ for TAC)

1: Enzyme-free; 2: Fructozyn BE; 3: Pectinex XXL; 4: Pectinex BE XXL

The clarified enzyme-free elderberry pulps presented the lowest antioxidant content compare the enzyme treatment samples. The highest values were shown by raw juice which treated with Fructozym BE enzyme in case of every antioxidant measurements.

The concentration of antioxidant compounds in MF permeate were lower to that in the original elderberry juice in case of all enzyme-treated samples. 
The FRAP values had range from 0.52 to $1.68 \mathrm{mmol}$ ascorbic acid equivalent / liter. After microfiltration between the four elderberry retentates and also between the permeates were not observed significant difference.

Total polyphenolic content were between 7.80 to $27.68 \mathrm{mg}$ gallic acid equivalent / liter. The results show significant differences of four enzyme treatment samples and also between the raw juice, retentate and permeate. The TPC values of permeates obtained after microfiltration of the enzyme-treated juice showed a high mean reduction $(\mathrm{p}<0.05)$ than the enzyme-free pulp.

The total anthocyanin content has the most difference between the samples. These results had range from 1.74 to $182.43 \mathrm{mg} / \mathrm{L}$. Decreasing anthocyanin concentration was measured enzyme-free pulps from raw juice to permeate.

\section{CONCLUSIONS}

The analytical results show that the MF membrane retained the valuable components. Significant losses are believed to have occurred after the MF clarification process due to fouling of membrane pores, what can be decreased with pectolytic enzymes treatment.

Research results of Reference [4] is the same, according to the reduction of the antioxidant capacity of the permeates obtained after microfiltration of the enzyme-treated juice was higher than that obtained using enzym-free pulp.

The best pectin hydrolysis and antioxidant component recovery were reached by using Fructozyn BE enzyme treatment due to the lowest fouling layer and polarization layer resistance. The results show that the pectolytic enzyme treatment had a positive effect on the microfiltration process of elderberry juice.

\section{ACKNOWLEDGEMENT}

The authors acknowledge the financial help of OTKA 84290.

\section{REFERENCES}

[1] L. Jungmin, E. Chad, Anthocyanins and other polyphenolics in American elderberry (Sambucus canadensis) and European elderberry (S. nigra) cultivars. Journal of the Science of Food and Agriculture, 87 (14) (2007), pp. 2665-2675.

[2] S. Andrzej, G. Anna, Advanced research on the antioxidant and health benefit of elderberry (Sambucus nigra) in food - a review. Journal of functional foods 18 (2015), pp. 941-958.

[3] L. Dawidowicz, D. Wilanowska, B. Baraniak, The antioxidant properties of alcoholic extracts from Sambucus nigra L. (antioxidant properties of extracts). LWT - Food Science and Technology, 39 (3) (2006), pp. 308-315.

[4] J. Yu, R. W. Lencki, Effect of enzyme treatments on the fouling behavior of apple juice during microfiltration. Journal of Food engineering 63 (4) (2004), pp. 413-423.

[5] L. Szalóki-Dorkó, F. Légrádi, L. Abrankó, M. Stéger-Máté, Effects of food processing technology on valuable compounds in elderberry (Sambucus nigra L.) varieties, Acta Biologica Szegediensis, 58 (1) (2014), pp. 45-48.

[6] R. M. D. Machado, R. N. Haneda, B. P. Trevisan, S. R. Fontes, Effect of enzymatic treatment on the cross-flow microfiltration of açaí pulp: Analysis of the fouling and recovery of phytochemicals, Journal of Food Engineering 113 (2012), pp. 442-452.

[7] Z. Dongjun, L. Evonne, H. Shan, I. M. Carmen, The effect of apple cider characteristics and membrane pore size on membrane fouling. LWT - Food Science and Technology. 64 (2) (2015), pp. 974-979.

[8] X. Hu, E. Bekassy-Molnar, A. Koris, Study of modelling transmembrane pressure and gel resistance in ultrafiltration of oily emulsion. Desalination, 163 (1-3) (2004), pp. 355-360. 
[9] F. Benzie, J. J. Strain, The ferric reducing ability of plasma (FRAP) as a measure of 'antioxidant power': The FRAP assay. Anal. Biochem. 239 (1) (1996), pp.70-76.

[10] V. L. Singleton, J. A. Rossi, Colorymetry of total phenolics with phosphomolybdic-phosphotunstic acid reagents. American Journal of Enology and Viticulture, 16 (3) (1965), pp. 144-158.

[11] T. Füleki, F. J. Francis, Quantitative methods for anthocyanins, Journal of Food Science, 33 (3) (1968), pp. 266-274. 